\title{
Gender Component of Internal Displacement in Ukraine: A Case of Business (In)Capability to Localize Human Rights Impact Assessment
}

\author{
Ganna Khrystova ${ }^{1}$ and Olena Uvarova ${ }^{2}$, (D) \\ ${ }^{1}$ Doctor of Juridical Science, Senior Project Officer (the Council of Europe Project Internal \\ Displacement in Ukraine: Building Solution') \\ ${ }^{2}$ Associate Professor, PhD, Head of the International Business and Human Rights Lab (Yaroslav Mudryi \\ National Law University), Kharkiv, Ukraine \\ *Corresponding author. Email: o.o.uvarova@nlu.edu.ua
}

Keywords: business capacity to assess gender equality risks; gender equality; internal displacement; localization of human rights due diligence; women's rights

\section{Introduction}

Human rights due diligence (HRDD) has become the buzzword of much of the advocacy and work today around business and human rights. ${ }^{1}$ It is almost commonplace that companies have the responsibility to identify, prevent, mitigate and account for how they address these adverse human rights impacts as part of their ongoing HRDD processes, in line with the UNGPs. ${ }^{2}$ The assessment of human rights impacts (HRIA) is a critical step in this process. ${ }^{3}$

However, every legislative regulation or self-regulation baseline requirements, voluntary guidelines and tools to equip companies with algorithms of HRDD developed by different state and non-state actors focus on a general human rights situation. Companies need to localize such general guidelines to the specific circumstances of their operation.

In this piece, the question of whether the business is able to cope with the challenge to identify human rights risks in situations of internal displacement by its own efforts is considered. The research is narrowed to the issue of the gender component of HRIA in the situation of internal displacement in Ukraine. What spheres of vulnerabilities of internally displaced women should be indicated by companies and what instruments could be relevant to identify such vulnerabilities, as well as risks to increase them by companies? What policies and procedures could be implemented for businesses to incorporate a gender-sensitive approach to human rights impact assessment in such a risky environment?

\footnotetext{
${ }^{1}$ Quijano, Gabriela and Lopez, Carlos, 'Rise of Mandatory Human Rights Due Diligence: A Beacon of Hope or Double-Edge Sword?' (2021) 6:2 Business and Human Rights Journal 1-14.

2 Jimenez-Damary, Cecilia, 'Promotion and protection of human rights: human rights questions, including alternative approaches for improving the effective enjoyment of human rights and fundamental freedoms. Human rights of internally displaced persons', Report of the Special Rapporteur on the human rights of internally displaced persons (2020), https://undocs.org/A/75/207 (accessed 31 May 2021).

${ }^{3}$ Danish Institute for Human Rights, 'Human Rights Impact Assessment Guidance and Toolbox', Ed. by Reynolds, Ashley Nancy, https://www.humanrights.dk/sites/humanrights.dk/files/media/document/DIHR\%20HRIA \%20Toolbox_Welcome_and_Introduction_ENG_2020.pdf, 10 (accessed 11 November 2021).
}

(c) The Author(s), 2022. Published by Cambridge University Press. 


\section{Internal Displacement as a High-Risk Environment Factor for Human Rights}

The number of people worldwide living in internal displacement has reached a record 55 million as of 31 December 2020. More than 85 per cent have fled conflict and violence. ${ }^{4}$ Nearly 1.5 million people from the temporarily occupied territories of the Donetsk and Luhansk oblasts and the Autonomous Republic of Crimea were registered as of May $2021 .^{5}$ This number of internally displaced persons (IDPs) put Ukraine in the top ten countries whose population was affected by forced displacement as a result of armed conflicts and violence. During the 'peak' of displacement, in terms of new IDPs, Ukraine came fourth globally after Yemen, Syria and Iraq. ${ }^{6}$ Women constituted 58-62 per cent of the entire number of IDPs in Ukraine (different sources give different numbers). These distressing data have highlighted the urgency of the gender dimension problem regarding the internal displacement in Ukraine and corporate responsibility to respect human rights of the IDPs.

In the context of the internal displacement and vulnerability of people affected by the conflict, the BHR framework has high importance for Ukraine. But if the situation of conflict and occupation, as a factor that increases the risks of human rights violations by business, is already the subject of academic research and legal regulation in the context of business responsible conduct, ${ }^{7}$ there is a complete gap in analysing the gender dimension of internal displacement and considering it through the lenses of responsible business conduct. At the same time, real life gives examples of business-related violations of human rights of internal displacement for women. More than half of internally displaced women report that they have been forced into informal employment because of the situation of vulnerability (they need to pay housing rent, they are not integrated into a new social community, they are often the only breadwinner in the family). ${ }^{8}$ The informality rate among IDPs at 34 per cent is more than twice higher than the average informality rate among all wage and salaried workers aged 15-70 years in Ukraine. ${ }^{9}$ Among internally displaced persons who have been actively seeking employment, 21 per cent are men and 79 per cent are women. Women claim that employers refuse them not just because they are IDPs, but because they are women with little children. ${ }^{10}$ Lack of job security, irregular employment, low salaries and delays in payments increase the risk for men and women to become victims of human trafficking. The

\footnotetext{
${ }^{4}$ Global Report on Internal Displacement 2021 (GRID 2021), https://reliefweb.int/report/world/global-reportinternal-displacement-2021-grid-2021 (accessed 31 May 2021).

${ }^{5}$ Unified information database on internally displaced persons in Ukraine, https://www.msp.gov.ua/news/ 19501.html (accessed 31 May 2021).

${ }^{6}$ Global report on internal displacement. IDMC and Norwegian Refugee Council, http://internal-displacemen t.org/assets/publications/2016/2016-global-report-internaldisplacementIDMC.pdf (accessed 31 May 2021).

${ }^{7}$ Azarova, Valentina, 'Business and Human Rights in Occupied Territory: The UN Database of Business Active in Israel's Settlements' (2018) 3 Business and Human Rights Journal 187-209; Farah, Marya and Abdallah, Maha, 'Security, Business and Human Rights in the Occupied Palestinian Territory' (2019) 4:1 Business and Human Rights Journal 7-31, doi.org/10.1017/bhj.2018.27; UN Working Group on Business and Human Rights , 'Business, human rights and conflict-affected regions: towards heightened action' (2020), https://www.ohchr.org/EN/Issues/Business/Pages/ ConflictPostConflict.aspx (accessed 31 May 2021).

8 'Zhinok-pereselenok na rynku pratsi dyskryminuyut' za genderom i vikom - doslidzhennya' (in Ukrainian) [Displaced women are discriminated on the basis of gender and age in the labor market - the research results], https://zmina.info/news/zhinokpereselenok_na_rinku_praci_diskriminujiut_za_jenderom_i_vikom_ta_stigmati zujiut_doslidzhennjia-2 (accessed 10 November 2021).

9 'Employment needs assessment and employability of internally displaced persons in Ukraine', Summary of survey findings and recommendations, International Labour Organization (2016), 20.

10 IOM: Survey Shows Displaced Women in Ukraine Desperate for Work (2019), https://www.iom.int/news/iomsurvey-shows-displaced-women-ukraine-desperate-work (accessed 10 November 2021).
} 
likelihood that IDPs engage in informal, unprotected employment is high, especially for women who are the majority of the adult workforce. ${ }^{11}$

\section{Gender Dimension of Forced Displacement}

A dedicated area of research and public discussion - 'Women and forced migration'12 - appeared in the 1980s. With the emergence in the early 1980s of an interdisciplinary area of research dedicated to forced migration (displacement), many scholars and practitioners who dealt with these issues became aware of the extensive decade-old feminist critique of social programmes and development programmes. ${ }^{13}$ Women in conditions of forced displacement had been given considerable attention since the mid-1980s and 1990s, 'becoming a fully legitimate, institutionalised element of forced migration discourse'. ${ }^{14}$ Most attention to these issues has been indisputably paid in the context of refugee rights..$^{15}$ IDPs have not crossed a border to find safety. ${ }^{16}$ Unlike refugees, they remain under the jurisdiction, and responsibility, of their governments. But in both cases, displacement is traumatic to women, and it causes vulnerability in the same significant manner. Moreover, some researchers state that usually the circumstances are worse for the internally displaced than for refugees, even though the situation in which the two will find themselves is similar. ${ }^{17}$

Despite a growing recognition of the fact that the experience of women in a situation of displacement differs from that of men, addressing this topic often reduces this experience to women's vulnerability as victims of sexual violence, instead of investigating how and why women become victims or if any other risks exist, and recognizing that women can be victims and remain active at the same time.

If a wider context was taken, the initial feminist studies of forced displacement in the conditions of the conflict were designed to make women and girls visible as a social group affected by the conflict and to document the risk of human rights violations pertaining to women. ${ }^{18}$ However, the corporate responsibility to respect women's rights remained mostly beyond the scope of attention.

Obviously, internal displacement affects each IDP, but women are impacted differently and could face disproportionate personal, economic and social risks. ${ }^{19}$ These gender-differentiated socio-economic risks must be recognized for an effective response. ${ }^{20}$

\footnotetext{
${ }^{11}$ Thematic Report: 'Conflict-Related Displacement in Ukraine: Increased Vulnerabilities of Affected Populations and Triggers of Tension within Communities', OSCE Special Monitoring Mission to Ukraine (2016), 10.

${ }_{12}$ Doreen, Indra (ed.), Engendering Forced Migration. Theory and Practice (New York: Berghahn Books, 1998).

${ }^{13}$ Hajdukowski-Ahmed, Maroussia, Khanlou, Nazilla and Moussa, Helene, Not Born A Refugee Woman. Contesting Identities, Rethinking Practices (New York: Berghahn Books, 2009).

${ }^{14}$ Indra, note 12.

${ }^{15}$ UNHRC, Position Paper on Gender-Related Persecution, with the Subsequent Adoption of the Guidelines on the Protection of Refugee Women (1991), https://www.unhcr.org/publications/legal/3d4f915e4/guidelines-pro tection-refugee-women.html (accessed 31 May 2021).

${ }^{16}$ Internally Displaced People, the UN Refugee Agency, https://www.unhcr.org/internally-displaced-peo ple.html (accessed 10 November 2021).

${ }^{17}$ Benjamin, Judy A, and Fancy, Khadija, 'The Gender Dimensions of Internal Displacement', Concept Paper and Annotated Bibliography (1998), 12.

${ }^{18}$ Fiddian-Qasmiyeh, Elena, Loescher, Gil, Long, Katy, Sigona, Nando, et al, Gender and Forced Migration, In The Oxford Handbook of Refugee and Forced Migration Studies (Oxford, Oxford University Press, 2016).

${ }^{19}$ ILO, The COVID-19 Response: Getting Gender Equality Right for a Better Future for Women at Work (2020), https://www.ilo.org/wcmsp5/groups/public/-dgreports/-gender/documents/publication/wcms_744685.pdf (accessed 31 May 2021).

${ }^{20}$ UNDP, How to Integrate Gender into Socio-Economic Assessments (2020), https://www.undp.org/content/ undp/en/home/librarypage/womens-empowerment/how-to-integrate-gender-into-socio-economic-assess ments.html (accessed 31 May 2021); UNWOMEN, Will The Pandemic Derail Hard-Won Progress on Gender Equality?
} 
Among the key vulnerability areas for women and girls in a situation of forced displacement, the following are often discussed in academic literature:

- limited access to livelihood and lack of services - medical, psychological or social - that would take gender aspects into consideration; ${ }^{21}$

- increased risk of sexual and other gender-based violence during the displacement and in the host community, which is often associated with economic vulnerability, lack of stable social ties or protection by friends and family; ${ }^{22}$

- increased risk of human trafficking (forced prostitution, domestic slavery, forced labour, forced begging); ${ }^{23}$

- unsafe working environment that, among other things, increases the risk of sexual harassment; ${ }^{24}$

- unpaid domestic work and caring for other family members; domestic violence. ${ }^{25}$

The UN Working Group admits that women tend to experience a disproportionate impact on their human rights in conflicts and post-conflict situations, settings that businesses may operate in, contribute to, or benefit from. ${ }^{26}$ The Working Group does not refer specifically to the problem of corporate responsibility to respect women's rights, although it notes that in crisis situations it is particularly felt that all forms of discrimination reflect a failure to integrate a gender perspective in laws, regulations, policies, plans, practices, processes and decisions. The current general business practice of gender-neutral human rights due diligence is a case in point. The Working Group further notes that a gendered approach to decision-making by States and businesses should also consider the intersectional nature of discrimination (women and girls in situations of

Spotlight on Gender, COVID-19 and the SDGs (2020), https://www2.unwomen.org/-/media/headquarters/attach ments/sections/library/publications/2020/spotlight-on-gender-covid-19-and-the-sdgs-en.pdf?la=en\&vs=5013 (accessed 31 May 2021).

21 Franz, Barabara, 'Bosnian Refugee Women in (Re)settlement: Gender Relations and Social Mobility' (2003) 73 Feminist Review 86-103.

${ }^{22}$ Holloway, Kerrie, Stavropoulou, Maria and Daigle, Megan, Gender in Displacement. The State of Play. Humanitarian Policy Group, Working Paper (2019), https://odi.org/en/publications/gender-in-displacementthe-state-of-play/ (accessed 31 May 2021); Formson, Constance and Hilhorst, Dorothea, The many faces of transactional sex: women's agency, livelihoods and risk factors in humanitarian contexts: a literature review. Secure Livelihoods Research Consortium. Working Paper 41 (London: ODI, 2016); Ritchie, Holly, 'Gender and Enterprise in Fragile Refugee Settings: Female Empowerment Amidst Male Emasculation - A Challenge to Local integration?' (2018) 42 Disasters 40-60; Sahoo, Dinabandhu and Mishra, Niharranjan, 'Development-Induced Displacement and Gender Injustice: Some Critical Reflections' (2016) 5:4 Journal of Politics \& Governance 19-29.

${ }^{23}$ Cardoso, Lauren, Shuman, Sara, et al, 'What Factors Contribute to Intimate Partner Violence Against Women in Urban, Conflict-Affected Settings? Qualitative findings from Abidjan, Côte d'Ivoire' (2016) 93:2 Journal of Urban Health 364-378; Levine, Simon, Ullah, Zaki, Khan, Saeed Ullah et al The Impact of Displacement on Gender Roles and Relations: The Case of IDPs from FATA (London: ODI, 2019); Lokot, Michelle, 'Syrian Refugees: Thinking Beyond Gender Stereotypes' (2018) 57 Forced Migration Review 33-35.

${ }^{24}$ Rohwerder, Brigitte, Women and girls in forced and protracted displacement (GSDRC, University of Birmingham, Birmingham, UK, 2016).

${ }^{25}$ Stark, Lindsay, and Ager, Alastair, 'A Systematic Review of Prevalence Studies of Gender-Based Violence in Complex Emergencies' (2011) 12:3 Trauma Violence Abuse 127-34.

${ }^{26}$ UN Working Group, Gender dimensions of the Guiding Principles on Business and Human Rights. Report of the Working Group on the issue of human rights and transnational corporations and other business enterprises. Human Rights Council, 24 June to 12 July 2019, https://documents-dds-ny.un.org/doc/UNDOC/GEN/G19/146/10/PDF/ G1914610.pdf? OpenElement (accessed 31 May 2021). 
internal displacement are an example of such intersectionality). However, while the Working Group mainly focuses on the issue of sexual and other gender-based violence, we believe that a broader view of the problem is necessary.

A key problem in the field of corporate activities is to recognize the existence of gender norms embedded in our daily life, of complex cultural stereotypes, and power imbalances in public and private relations. While the company itself cannot change the context, it should be aware of and recognize the situations that increase vulnerability of women or their specific groups, compared with other participants in the same sector of relations. The company should ensure that its operation does not advance the existing negative practices, and that the company does benefit from stereotypes or gender inequality. ${ }^{27}$ This is why integration of a gender component in internal displacement cannot be achieved by merely adding it to the HRDD procedures.

\section{Vulnerability of Women in Situations of Internal Displacement in Ukraine}

The research was based on the results of a survey of 280 individuals. The goal of the survey was to indicate the key areas of vulnerability of internally displaced women and to obtain quantitative estimates for the development of the model of gender component's incorporation into a human rights risks assessment mechanism. The research involved representatives of local authorities, civil activists, including IDPs, lawyers and business representatives from four different Ukrainian regions (the regions were selected based on the official data about the number of IDPs in the region). The respondents represented different age categories, marital status, level of education, and fields of activity. They were selected by the open call. ${ }^{28}$

The questionnaire for the survey was developed based on a literature review (key areas of women's vulnerability were indicated), desk study results and focus groups (16 focus groups were conducted) where the following questions were discussed:

(1) What are the traditional roles of women, girls, boys, men, and who controls resources in households and society? Are any gender groups in society facing discrimination - including their ability to access housing, employment, access to justice, etc. - and are any particularly vulnerable?

(2) How do armed conflict and internal displacement affect different gender groups and their roles?

(3) What are the opportunities for different groups to overcome, respond and recover in a situation of internal displacement?

(4) What special needs for assistance and protection do women, girls, boys and men have in situations of internal displacement?

(5) Are there particularly vulnerable groups to which certain types of assistance should be directed?

As a result, the key areas of vulnerability of women in situations of internal displacement were indicated:

\footnotetext{
${ }^{27}$ Bourke Martignoni, Joanna, and Umlas, Elizabeth, 'Gender-Responsive Due Diligence For Business Actors: Human Rights-Based Approaches' (2018) 12 The Geneva Academy of International Humanitarian Law and Human Rights, Academy Briefing 6-18.

${ }^{28}$ The survey was conducted in person in several stages with a grant support provided by the Council of Europe Project 'Internal Displacement in Ukraine: Building Solutions', https://www.coe.int/en/web/kyiv/idps2 (accessed 11 November 2021).
} 


\section{a. Housing needs}

a.i. Additional challenges for women are due to the fact that, on average, lower incomes make it more difficult for women to buy a house/apartment, especially when women are the heads of households.

a.ii. It is common in Ukraine when a formal lease agreement is not concluded (due to landlords' desire to avoid taxation of rental income). It has a negative impact on IDPs, as they cannot claim social benefits without a formal agreement. This situation affects women, who statistically earn less, more seriously than men.

\section{b. Employment and entrepreneurship}

b.i. The barrier to employment may be the need to care for children (even if the child goes to kindergarten or school, as usually she or he does not stay there all the working hours of the parents; statistically, women are more likely than men to deal with logistics issues for the child's stay in different educational institutions).

b.ii. Women receive statistically lower wages (according to the Ministry of Social Policy in Ukraine, the gender wage gap is $25 \%$ ), which increases the vulnerability of IDPs, as wages must be sufficient for housing and other basic needs. This is often an additional reason for women to refuse formal employment and to be employed informally.

b.iii. The stereotypical division of professions into women's and men's professions is a significant barrier to women's access to a number of highly paid professions, although there is no formal prohibition.

b.iv. IDPs face denials of employment by employers more often than other jobseekers; IDP women, especially those who have children and/or those aged 40 and over, are a particularly vulnerable group.

b.v. Banks refuse to provide loans and other financial instruments for women more often than men, especially when it comes to additional risks - the status of IDPs.

b.vi. Internal displacement makes women more vulnerable to sexual harassment in the workplace.

c. Family disputes (divorce; alimony for child; determination of the child's place of residence; deprivation of parental rights)

c.i. There are situations when a woman with a child/children lives in the territory controlled by Ukraine, and a man (father of the child/children) lives in the uncontrolled area (or is not registered in the controlled territory). This causes significant difficulties to access justice.

d. Domestic violence

d.i. The risk of domestic violence, primarily due to the impact of a stressful situation.

d.ii. The situation of internal displacement breaks the usual social ties, and can also increase the economic dependence of women on men. 
e. Human trafficking and modern slavery, gender-based violence

e.i. Human trafficking/modern slavery, gender-based violence: people are looking for an opportunity to earn a living in conditions of limited employment opportunities, and accept dubious offers of employment.

\section{f. Receiving social and pension benefits}

f.i. The legislation of Ukraine contains a number of restrictions for internally displaced persons, compared with other citizens of Ukraine: the obligation to use only the services of Sberbank to receive pension benefits; and the need for identification for the use of banking services to receive pension and other social benefits every three months.

Findings of the study based on the conducted survey and interviews may serve as the basis for integrating the gender component in the businesses' HRDD procedures. Gender discrimination is largely invisible: it cannot be detected by standard human rights risk assessments. Companies must explicitly raise gender issues in due diligence processes, otherwise it is unlikely that they would be able to identify them. In other words, the company's actions will only be effective if, from the very outset, the respective company, on the basis of a preliminary review of data, analytical materials, and reports from human rights organizations would make assumptions about potential risk areas. Apart from these common challenges, however, the company must also raise the issue of additional vulnerabilities manifested in certain groups of women, in particular women - IDPs.

\section{Gender Component's Incorporation into HRDD in Situations of Internal Displacement}

The model of gender component's incorporation into corporate human rights policies to ensure responsible business conduct in situation of internal displacement covers the following basic components:

I. Indicating the spheres of vulnerability of women in situations of internal displacement. In the Ukrainian case, the spheres that are relevant for all businesses are as follows: (1) housing needs; (2) employment and entrepreneurship; (3) family disputes (divorce; alimony for child; determination of the child's place of residence; deprivation of parental rights); (4) domestic violence; (5) human trafficking and modern slavery, gender-based violence; (6) receiving social and pension benefits.

Companies cannot identify the vulnerability of women in situations of internal displacement by the usual human rights risk assessment. Identifying areas of vulnerability that are relevant to a particular company requires a preliminary formulation of the potential risks of disproportionate impact on internally displaced women of a particular situation.

II. An analysis of the areas of vulnerability of women in a situation of internal displacement proves that a number of vulnerability factors can be identified and minimized solely through self-regulation of the company, and not through government regulation. 
Companies which operate in such a high-risk business environment as a situation of internal displacement should recognize that the models of operating based on the standards of responsible business conduct effectively balance the competing interests of different individuals. Such models minimize the risks of negative impact to the vulnerable groups and offer more flexible and effective tools to respond to global threats. Each company in conflict-affected areas should develop its unique individual model - a set of practical tools for gender aspects' incorporation into business policies and enshrine it in self-regulatory acts. The lack of capacities of business, especially SMEs, calls companies to cooperate with the CSOs and academia. CSOs have a special importance in the post-Soviet region as a region without strong tradition of human rights respect. These institutions have appropriate human rights knowledge and experience of human rights protection.

Today, corporate observance of human rights requires more than formal compliance with the law. In doing this, 'wearing gender glasses', i.e., merely filtering out the existing mechanisms of human rights due diligence, would not be enough. A key problem in the field of corporate activities is to recognize the existence of gender norms embedded in our daily life, of complex cultural stereotypes, and power imbalances in public and private relations. While the company itself cannot change the context, it should be aware of and recognize the situations that increase vulnerability of women or their specific groups, compared with other participants in the same sector of relations. The company should ensure that its operation does not advance the existing negative practices, and that the company does not benefit from stereotypes or gender inequality.

Conflicts of interest. Olena Uvarova and Ganna Khrystova declare none.

Funding. The research has been funded by the Council of Europe project 'Internal Displacement in Ukraine: Building Solutions' as part of conducting the survey. The results of the survey have been used in this research. 